\title{
REVIEW KARYA TULIS ILMIAH SEBAGAI ACUAN DALAM PENCIPTAAN SUATU KARYA BUSANA ARTWEAR BERGAYA BOHEMIAN
}

\author{
Rofifah Muthiah Ramadhan ${ }^{1}$ \\ (Program Studi Pendidikan Tata Busana, Universitas Pendidikan Indonesia, muthiah.rofifah@gmail.com, 0895361211640) \\ Suciati $^{2}$ \\ (Program Studi Pendidikan Tata Busana, Universitas Pendidikan Indonesia, suciati@upi.edu)
}

\begin{abstract}
Create a bohemian style of art wear by macramé by making craftwork in the field of fashion in the form of a leaf-shaped macrame technique by taking the concept of autumn, this macrame leaf is applied to the form of clothing with the theme of art wear by adopting a bohemian style. Various scientific papers in the form of journals, articles, and thesis become a reference for the analysis of the work being made. The purpose of reading various scientific papers, the writer gets an imagination in the creation of this work. The method used is by identifying ten scientific papers in the form of journals, articles, undergraduate thesis, thesis, and learning modules related to making art wear with macramé techniques in bohemian style. By analyzing the problems, objectives, benefits, methodology, results, or findings contained in the scientific papers, it is the beginning of the process for the writer to get ideas related to the creation of textile craftwork. The activity of reviewing scientific papers makes a picture in the creation of a work with reliable sources in the form of their research.
\end{abstract}

Keywords: artwear, bohemian, creation, imagination, macrame, review, scientific papers

\section{ABSTRAK}

Pembuatan artwear dengan teknik makrame bergaya bohemian dengan membuat suatu karya kriya di bidang busana berupa teknik makrame berbentuk daun daun dengan mengambil konsep musim gugur, yang diaplikasikan ke dalam bentuk busana dengan tema artwear dengan mengadopsi gaya bohemian. Berbagai karya tulis ilmiah berupa jurnal, artikel, dan thesis menjadi acuan analisis dalam pembuatan karya. Tujuan dari membaca berbagai karya tulis ilmiah tersebut, agar penulis mendapatkan gambaran dalam penciptaan karya ini. Metode yang dilakukan yaitu dengan cara mengidentifikasi sepuluh karya tulis ilmiah berupa jurnal, artikel, thesis, skripsi, dan modul pembelajaran yang berhubungan dengan pembuatan artwear dengan teknik makrame pada bohemian style. Dengan menganalisis permasalahan, tujuan, manfaat, metodologi, hasil, atau penemuan yang terkandung dalam karya tulis ilmiah tersebut dapat dijadikan awal proses untuk penulis mendapatkan ide ide terkait penciptaan suatu karya busana kriya tekstil ini. Kegiatan mereview karya tulis ilmiah ini menjadikan gambaran dalam penciptaan suatu karya dengan berbagai sumber yang terpercaya berupa hasil penelitian.

Kata Kunci: artwear, bohemian, penciptaan, gambaran, makrame, review, karya tulis ilmiah 


\section{PENDAHULUAN}

Dalam membuat suatu karya atau menghasilkan penemuan baru dibutuhkan karya ilmiah sebagai sumber atau acuan dalam proses pembuatannya. Dengan karya ilmiah pencipta dapat memahami tentang apa yang akan dibuat berdasarkan pemahaman dan keilmuan dari karya ilmiah yang berhubungan dengan penciptaan karya dan penemuan selanjutnya.

Menurut Munawar Syamsudin (1994), tulisan ilmiah adalah naskah yang membahas suatu masalah tertentu, atas dasar konsepsi keilmuan tertentu, dengan memilih metode penyajian tertentu secara utuh, teratur dan konsisten. Ragam karya ilmiah sendiri terdiri atas beberapa jenis berdasarkan fungsinya. Menurut pengelompokan itu, dikenal ragam karya ilmiah seperti (makalah, skripsi, tesis, dan disertasi (Yamilah dan Samsoerizal 1994 : 90)

Karya ilmiah (scientific paper) adalah laporan tertulis dan diterbitkan yang memaparkan hasil dari penelitian atau pengkajian yang telah dilakukan oleh seseorang atau sebuah tim dengan memenuhi kaidah dan etika keilmuan yang dikukuhkan dan ditaati oleh masyarakat keilmuan

Berbagai sumber karya ilmiah didapatkan mengenai pembuatan artwear dengan teknik makrame pada bohemian style. Artwear yang dimaksud adalah suatu busana yang memiliki nilai estetik tinggi dan diproduksi sesuai momen atau style tertentu (Valerie,2005). Artwear ini dibuat menggunakan teknik dari pembelajaran kriya tekstil yaitu teknik makrame dengan tema daun musim gugur. Kata makrame berasal dari bahasa Turki. (Turki: Ma-kra'ma atau Miqramah) Dalam Kamus Besar Bahasa Indonesia, dijelaskan : bentuk suatu kerajinan simpul-menyimpul dengan menggarap rangkaian benang pada awal atau akhir suatu hasil tenunan, dengan membuat berbagai simpul pada rantai benang tersebut, sehingga terbentuk aneka rumbai dan jumbai. Gaya busana Bohemian terbentuk akibat dari perlawanan terhadap kultur mainstream yang secara simbolis diekpresikan dalam bentuk penciptaan gaya (Sahertian 2018). Bohemian identik dengan busana yang sederhana dengan dominasi warna alam, siluet yang loose-fitting, material natural, soft, dan menerawang yang melambai, ber-layer, motifmotif tertentu dan aksesoris yang bold (Sahertian, 2018). Hal yang kemudian memunculkan bohemian style melalui sisi teknik makrame pada pembuatan artwear.

Dalam informasi mengenai pembuatan artwear dengan teknik makrame pada bohemian style, ada berbagai jenis karya ilmiah (Goyena 2019) yang menjadi sumber review yaitu :

1. Artikel (Jurnal IImiah), dalam istilah jurnalistik, artikel adalah tulisan berisi pendapat subjektif penulis nya tentang suatu masalah atau peristiwa.

2. Kertas Kerja, work paper atau Kertas kerja pada prinsipnya sama dengan makalah, namun dibuat dengan analisis lebih dalam dan tajam serta dipresentasikan pada seminar atau lokakarya yang biasanya dihadiri oleh ilmuwan.

3. Makalah, karya tulis ilmiah yang menyajikan suatu masalah yang pembahasannya berdasarkan data di lapangan yang bersifat empiris-objektif.

4. Skripsi, karya tulis ilmiah mahasiswa untuk menyelesaikan jenjang studi S1 (Sarjana). Skripsi berisi tulisan sistematis yang mengemukakan pendapat penulis berdasarkan pendapat (teori) orang lain.

5. Buku, kumpulan kertas atau bahan lainnya yang dijilid menjadi satu pada salah satu 
ujungnya dan berisi tulisan, gambar, atau tempelan.

6. Tesis / Disertasi, karya tulis ilmiah yang dibuat sebagai prasyarat dalam menyelesaikan Program Studi Magistera atau S2. Disertasi adalah karya tulis ilmiah prasyarat Program Studi Doktoral atau S3.

Pada dasarnya kesemuanya itu merupakan produk dari kegiatan ilmuwan. Data, simpulan, dan informasi lain yang terkandung dalam karya ilmiah tersebut dijadikan acuan pengkajian dari pembuatan artwear dengan teknik makrame pada bohemian style. Untuk memahami suatu karya tulis ilmiah pastinya dibutuhkan pemahaman dalam memaknai setiap tulisan, salah satunya dengan cara mereview secara keseluruhan. Hasil dari kegiatan review tersebut, dapat memberikan kita sebagai pembaca pemahaman dengan baik tentang isi dan tujuan dari penulis. Review dapat digunakan untuk membantu pembaca untuk memahami isi karya tulis ilmiah secara ringkas sehingga dapat mengerti isi karya tulis ilmiah berdasarkan pandangan dari karya tulis ilmiah.

Review ilmiah adalah sebuah proses atau tulisan yang disusun untuk membedah sebuah makalah ilmiah. Membaca dan menulis ulasan atau review karya tulis ilmiah seperti skripsi, tesis, buku, hingga jurnal penelitian merupakan salah satu skill yang wajib dimiliki seorang akademisi (Karomah, 2020). Kegiatan ini bertujuan menilik seberapa jauh perkembangan ilmu pengetahuan serta memperkuat dasar-dasar keilmuan yang dimiliki oleh seorang akademisi. Umumnya seorang akademisi mereview sebuah makalah penelitian untuk tugas, mencari metode atau dasar teori penelitian, dan menyusun state of the art suatu topik (Karomah, 2020).
Penulis bermaksud untuk membuat penciptaan suatu karya dalam busana kriya yaitu menciptakan "gaya bohemian pada busana artwear dengan menggunakan teknik makrame" Akan tetapi sebagai pencipta pastinya membutuhkan riset terlebih dahulu dengan unsur unsur dalam penciptaan karya. Dengan bantuan beberapa tulisan karya tulis ilmiah dapat membantu penulis untuk mendapatkan informasi mengenai hal hal yang berhubungan dengan penciptaan karya busana.

Maka dari itu penulis bertujuan mereview beberapa karya tulis ilmiah guna untuk menjadikan acuan dan sumber sebagai gambaran dalam penciptaan suatu karya. Terdapat sepuluh karya tulis ilmiah yang penulis gunakan untuk direview guna nantinya membantu penulis membuat penciptaan karya.

\section{HASIL DAN PEMBAHASAN}

Menurut hasil review dari sepuluh karya tulis ilmiah yang menunjang informasi penciptaan suatu karya dalam busana kriya yaitu "gaya bohemian pada busana artwear dengan menggunakan teknik makrame" dapat dikemukakan melalui tabel di bawah ini.

\begin{tabular}{|c|c|c|}
\hline No & $\begin{array}{l}\text { Bagian bagian } \\
\text { penelitian }\end{array}$ & Pertanyaan \\
\hline 1 & Judul & $\begin{array}{l}\text { Apakah judul karya tulis } \\
\text { ilmiah tersebut? }\end{array}$ \\
\hline 2 & Penulis & $\begin{array}{l}\text { Siapa penulis karya tulis } \\
\text { IImiah tersebut? }\end{array}$ \\
\hline 3 & Permasalahan & $\begin{array}{l}\text { Apakah permasalahan } \\
\text { yang ditunjukan dari } \\
\text { penulisan tersebut? }\end{array}$ \\
\hline 4 & Tujuan & $\begin{array}{ll}\text { Apakah tujuan dari } \\
\text { penulisan karya tulis } \\
\text { ilmiah tersebut }\end{array}$ \\
\hline
\end{tabular}




\begin{tabular}{|c|c|c|}
\hline 5 & Manfaat & $\begin{array}{l}\text { Apakah manfaat dari } \\
\text { Penulisan karya tulis } \\
\text { ilmiah tersebut }\end{array}$ \\
\hline 6 & Metode & $\begin{array}{l}\text { Apakah metode yang } \\
\text { digunakan oleh penulis } \\
\text { dalam penulisan karya } \\
\text { tulis ilmiah tersebut? }\end{array}$ \\
\hline 7 & Temuan/Hasil & Apakah temuan atau \\
\hline
\end{tabular}

\section{HASIL DAN PEMBAHASAN}

Menurut hasil review dari 10 karya tulis ilmiah yang menunjang informasi penciptaan suatu karya dalam busana

\begin{tabular}{ll}
\hline hasil dari penulisan \\
karya tulis ilmiah yang \\
dibuat oleh penulis?
\end{tabular}

kriya yaitu "gaya bohemian pada busana artwear dengan menggunakan teknik makrame" dapat di kemukakan melalui tabel dibawah ini.

\begin{tabular}{|c|c|c|c|c|c|}
\hline Aspek & Artikel 1 & $\begin{array}{c}\text { Modul } \\
\text { Pembelajaran } 2\end{array}$ & Thesis 3 & Artikel 4 & Skripsi 5 \\
\hline
\end{tabular}

\begin{tabular}{|c|c|c|c|c|c|}
\hline \multirow{7}{*}{ Judul } & \multicolumn{3}{|l|}{ Kenapa } & \multicolumn{2}{|c|}{ With Art and Fashion Pengembangan } \\
\hline & Daun & & Perancangan & Collaborating ike & Modul Kerajinan \\
\hline & Berubah & & Informasi Gaya & Never Before, We & Makrame untuk \\
\hline & $\begin{array}{l}\text { Warna Dan } \\
\text { Bergugura }\end{array}$ & Morfologi Daun & $\begin{array}{l}\text { Bohemian Sebagai } \\
\text { Alternatif Gava }\end{array}$ & Look at Some of & Pembelajaran \\
\hline & n Pada & & Berbusana Melalui & History's Most & Keterampilan PKK di \\
\hline & Musim & & Media Lookbook & Important & $\begin{array}{l}\text { SMP Negeri } 1 \\
\text { Yogvakarta }\end{array}$ \\
\hline & Gugur? & & & & \\
\hline
\end{tabular}

Penulis Keni Vidilaseris Hadisunarso $\begin{gathered}\text { Febi Ramdani } \\ \text { Hakim }\end{gathered} \quad$ Team we hearth Sartini




\begin{tabular}{|c|c|c|c|c|c|}
\hline $\begin{array}{l}\text { Permasalah } \\
\text { an }\end{array}$ & $\begin{array}{l}\text { Megapa pada } \\
\text { musim gugur } \\
\text { atau autumn } \\
\text { hanya } \\
\text { tumbuhan } \\
\text { yang berdaun } \\
\text { lebar, seperti } \\
\text { pohon maple } \\
\text { dan oaks daun } \\
\text { daunnya yang } \\
\text { sebelumnya } \\
\text { berwarna hijau } \\
\text { berubah warna } \\
\text { menjadi } \\
\text { kuning atau } \\
\text { merah dan } \\
\text { kecokelatan, } \\
\text { kemudian } \\
\text { berguguran } \\
\text { sedangkan } \\
\text { tumbuhan } \\
\text { berdaun jarum } \\
\text { seperti pohon } \\
\text { pinus tidak } \\
\text { berubah } \\
\text { warnanya } \\
\text { sepanjang } \\
\text { tahun dan juga } \\
\text { tidak } \\
\text { menggugurkan } \\
\text { daunnya } \\
\text { berubah } \\
\text { warnanya } \\
\text { sepanjang } \\
\text { tahun dan juga } \\
\text {.... }\end{array}$ & $\begin{array}{l}\text { Faktor yang } \\
\text { mempengaruhi } \\
\text { bagian dan } \\
\text { bentuk daun } \\
\text { berbagai macam } \\
\text { tumbuhan } \\
\text { berbeda }\end{array}$ & $\begin{array}{l}\text { Sebagian } \\
\text { masyarakat yang } \\
\text { belum mengetahui } \\
\text { arti dari gaya } \\
\text { Bohemian dan } \\
\text { sebagian } \\
\text { masyarakat yang } \\
\text { belum mengetahui } \\
\text { gaya berbusana } \\
\text { Bohemian } \\
\text { merupakan gaya } \\
\text { yang menarik yang } \\
\text { dapat menjadi } \\
\text { alternatif dan } \\
\text { referensi dalam } \\
\text { gaya berbusananya }\end{array}$ & $\begin{array}{l}\text { Fashion, yang } \\
\text { sering dihakimi } \\
\text { secara tidak adil } \\
\text { sebagai salah satu } \\
\text { seni terapan yang } \\
\text { lebih sembroo } \\
\text { dan mendapatkan } \\
\text { cap serius melalui } \\
\text { asosiasi, } \\
\text { sementara } \\
\text { seniman dapat } \\
\text { menjangkau } \\
\text { secara luas dan } \\
\text { lebih banyak } \\
\text { khalayak }\end{array}$ & $\begin{array}{l}\text { Usaha } \\
\text { mengembangkan } \\
\text { manusia } \\
\text { berkualitas yang } \\
\text { siap menghadapi } \\
\text { berbagai } \\
\text { tantangan hidup } \\
\text { dimulai sedini } \\
\text { mungkin melalui } \\
\text { pendidikan, } \\
\text { Muatan lokal } \\
\text { keterampilan PKK } \\
\text { melatih } \\
\text { keterampilan } \\
\text { siswa salah } \\
\text { satunya membuat } \\
\text { kerajinan tangan } \\
\text { berupa kerajinan } \\
\text { makrame. Namun } \\
\text { tidak semua siswa } \\
\text { mampu } \\
\text { menghasilkan } \\
\text { produk makrame } \\
\text { dengan baik }\end{array}$ \\
\hline
\end{tabular}




\begin{tabular}{|c|c|c|c|c|c|}
\hline Tujuan & $\begin{array}{l}\text { Mengidentifikasi dan } \\
\text { memahami faktor- } \\
\text { faktor apa yang } \\
\text { mempengaruhi } \\
\text { pohon maple dan } \\
\text { oaks berubah warna } \\
\text { dan menggugurkan } \\
\text { dedaunnya pada } \\
\text { musim gugur }\end{array}$ & $\begin{array}{l}\text { Mengetahui } \\
\text { jaringan } \\
\text { tumbuhan, } \\
\text { susunan anatomi } \\
\text { daun, dan bagian, } \\
\text { bentuk, warna } \\
\text { daun dari berbagai } \\
\text { macam tumbuhan }\end{array}$ & $\begin{array}{l}\text { Untuk } \\
\text { mengetahui } \\
\text { informasi } \\
\text { mengenai gaya } \\
\text { berbusana } \\
\text { Bohemian }\end{array}$ & $\begin{array}{l}\text { Mengetahui } \\
\text { kolaborasi antara } \\
\text { fesyen dan seni } \\
\text { yang sedang berada } \\
\text { dipuncaknya sudah } \\
\text { sejak dari dulu dan } \\
\text { bukan fenomena } \\
\text { baru dengan } \\
\text { inovasi, revolusi } \\
\text { yang membawa } \\
\text { keduanya menjadi } \\
\text { sesuatu yang luar } \\
\text { biasa }\end{array}$ & $\begin{array}{l}\text { Mengetahui simpul } \\
\text { simpul teknik } \\
\text { makrame secara } \\
\text { mudah dengan } \\
\text { beberapa modul } \\
\text { sebagai sumber } \\
\text { belajar yang } \\
\text { diberikan oleh } \\
\text { penulis }\end{array}$ \\
\hline Manfaat & $\begin{array}{l}\text { Mengetahui apa yang } \\
\text { membuat daun daun } \\
\text { pada pohon oaks dan } \\
\text { maple berubah } \\
\text { warna dan dapat } \\
\text { berguguran ketika } \\
\text { musim gugur atau } \\
\text { autumn datang }\end{array}$ & $\begin{array}{l}\text { Mengetahui apa } \\
\text { saja kandungan } \\
\text { pada tumbuhan } \\
\text { yang bisa } \\
\text { menghasilkan } \\
\text { bentuk, warna } \\
\text { yang berbeda dari } \\
\text { variasi tumbuhan. } \\
\text { Fungsi lainnya } \\
\text { digunakan untuk } \\
\text { membantu } \\
\text { mengidentifikasi } \\
\text { tumbuhan }\end{array}$ & $\begin{array}{l}\text { Mengetahui apa } \\
\text { itu Bohemian, } \\
\text { sejarah } \\
\text { Boheniam, lini } \\
\text { masa Boheniam } \\
\text { style sehingga } \\
\text { memberikan dan } \\
\text { menambah } \\
\text { pengetahuan } \\
\quad \text { mengen } \\
\text { ai gaya Bohemian } \\
\text { serta } \\
\text { memberikan } \\
\text { referensi gaya } \\
\text { berbusana } \\
\text { Bohemian }\end{array}$ & $\begin{array}{l}\text { Mengetahui awal } \\
\text { mula } \\
\text { perkembangan } \\
\text { kolaborasi fashion } \\
\text { dan seni serta saling } \\
\text { ketergantungan } \\
\text { keduannya }\end{array}$ & $\begin{array}{l}\text { Dengan mengetahui } \\
\text { berbagi teknik } \\
\text { makrame dengan } \\
\text { mudah dapat } \\
\text { membantu siswa } \\
\text { mempraktikannya } \\
\text { dengan baik sehingga } \\
\text { membantu siswa } \\
\text { membuat produk } \\
\text { makrame yang rapi } \\
\text { dan baik }\end{array}$ \\
\hline
\end{tabular}




\begin{tabular}{|c|c|c|c|c|c|}
\hline Metode & $\begin{array}{l}\text { Metode } \\
\text { pengumpulan data } \\
\text { adalah dengan jalan } \\
\text { wawancara }\end{array}$ & $\begin{array}{l}\text { Metode penelitian } \\
\text { yang dilakukan } \\
\text { adalah penelitian } \\
\text { deskriptif kualitatif }\end{array}$ & $\begin{array}{l}\text { Metode } \\
\text { Penelitian } \\
\text { dengan metode } \\
\text { kuesioner ini } \\
\text { dilakukan untuk } \\
\text { mengetahui } \\
\text { pengetahuan dan } \\
\text { ketertarikan } \\
\text { masyarakat } \\
\text { mengenai gaya } \\
\text { berbusana } \\
\text { Bohemian }\end{array}$ & $\begin{array}{l}\text { Metode penelitian } \\
\text { yaitu berupa } \\
\text { Pendekatan } \\
\text { Penelitian Historis } \\
\text { dengan penelitian } \\
\text { yang dilakukan } \\
\text { dengan } \\
\text { merekonstruksi } \\
\text { masa lampau dari } \\
\text { awal mula } \\
\text { perkembangan } \\
\text { kolaborasi dunia } \\
\text { seni dan dunia } \\
\text { mode. Jenis } \\
\text { Penelitian berupa } \\
\text { penelitian survey } \\
\text { dengan } \\
\text { mengumpulkan }\end{array}$ & $\begin{array}{l}\text { Penelitian ini } \\
\text { menggunakan } \\
\text { Pendekatan Research } \\
\text { and Development } \\
\text { (R\&D). } \\
\text { mengembangkan } \\
\text { produk pendidikan } \\
\text { efektif yang berupa } \\
\text { material } \\
\text { pembelajaran, } \\
\text { media, strategi atau } \\
\text { material lainnya } \\
\text { dalam pembelajaran } \\
\text { untuk digunakan di } \\
\text { sekolah }\end{array}$ \\
\hline
\end{tabular}

berbagai informasi

tentang beberapa tokoh

perancang dunia mode

kolaborasi dengan tokoh

seniman yang

menghasilkan busana

unik yang memilki nilai

seni tinggi 


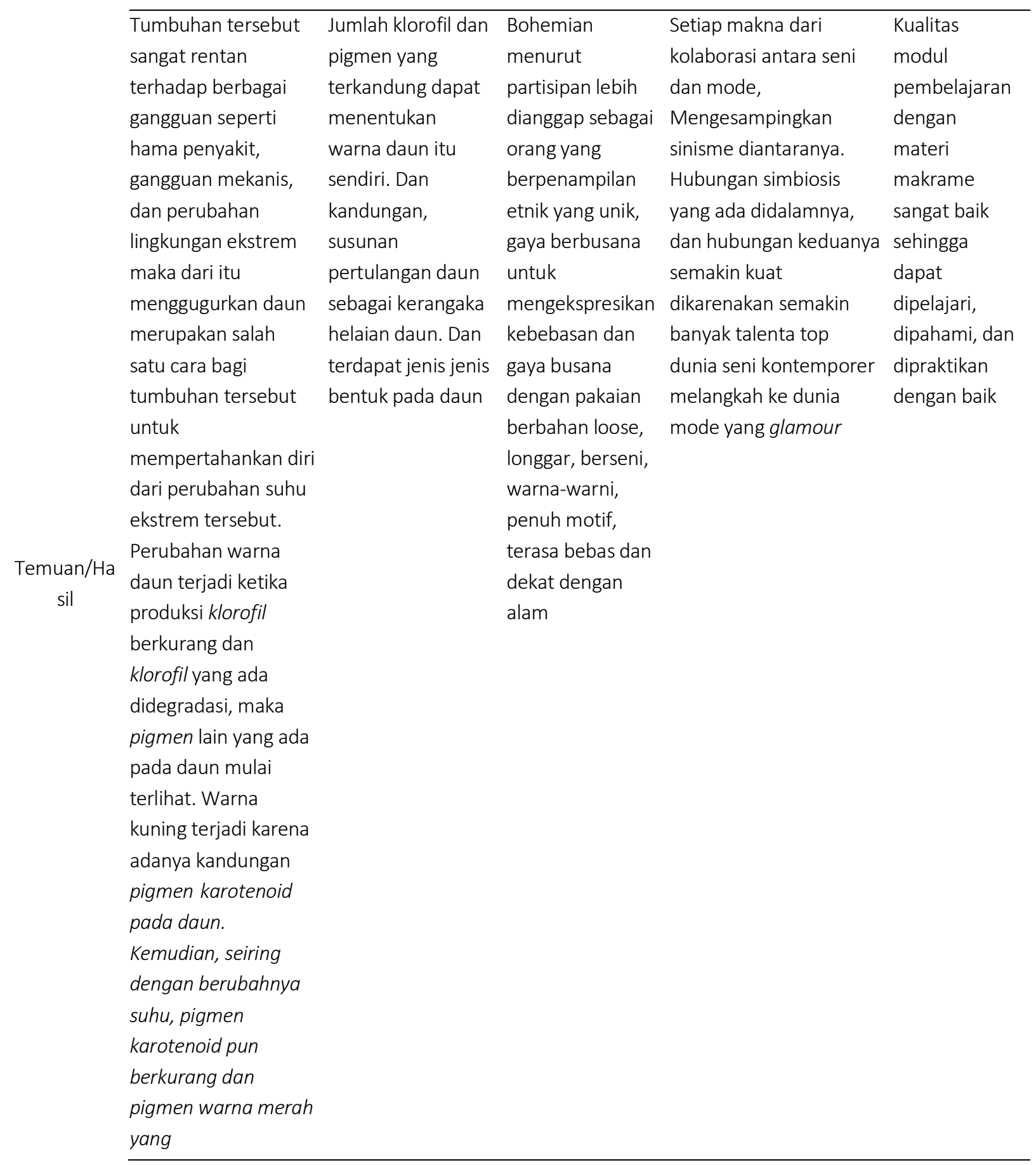



disebabkan oleh
antosianin akan
terlihat. Ketika
semua pigmen
tersebut sudah
terdegradasi, daun
akan menjadi
berwarna cokelat
yang disebabkan
karena pigmen
tanin yang tersisa

Tabel 2. Table create style bohemian of artwear by macramé technique.

\begin{tabular}{|c|c|c|c|c|c|}
\hline Aspek & Tugas Akhir 6 & Skripsi 7 & Jurnal 8 & Jurnal 9 & Jurnal 10 \\
\hline Judul & $\begin{array}{l}\text { Motif Daun Maple } \\
\text { dalam Busana Kasual }\end{array}$ & $\begin{array}{l}\text { Kelelawar sebagai } \\
\text { Sumber Ide } \\
\text { Penciptaan Busana } \\
\text { Artwear }\end{array}$ & $\begin{array}{l}\text { Fashion sebagai } \\
\text { Bentuk Ekspresi } \\
\text { Diri dalam } \\
\text { Komunikasi }\end{array}$ & $\begin{array}{l}\text { Surface Cording } \\
\text { Apllications in } \\
\text { Award Gown }\end{array}$ & $\begin{array}{l}\text { Komparatif Teknik } \\
\text { dan Ekspresi } \\
\text { dalam Seni Kriya }\end{array}$ \\
\hline Penulis & Olivia Pradhista Dewi & Dita Retnowati & Tri Yulia Trisnawati & Liza Putri Renata & I Wayan Suardana \\
\hline Permasalahan & $\begin{array}{l}\text { Pembuatan batik } \\
\text { motif daun } \\
\text { Maple } \\
\text { sedangkan } \\
\text { pohon Maple } \\
\text { tidak ada di } \\
\text { Indonesia, pohon } \\
\text { Maple hanya } \\
\text { hidup di negara } \\
\text { subtropis }\end{array}$ & $\begin{array}{l}\text { Manusia hidup } \\
\text { berdampingan } \\
\text { bersama makhluk } \\
\text { hidup lain, } \\
\text { bersosialisasi } \\
\text { dengan sesamanya } \\
\text { di alam sekitar, } \\
\text { menjadi inspirasi } \\
\text { bagi-nya dan } \\
\text { dituangkan } \\
\text { kedalam artwear } \\
\text { sebagai media } \\
\text { dalam berkarya. } \\
\text { Dengan } \\
\text { memanfaatkan } \\
\text { mamalia terbang } \\
\text { yaitu kelelawar } \\
\text { sebagai }\end{array}$ & $\begin{array}{l}\text { Fashion sebagai } \\
\text { ekspresi diri dan } \\
\text { komunikasi dari } \\
\text { pemakainya } \\
\text { memberikan } \\
\text { implikasi bagi } \\
\text { penggunaan } \\
\text { fashion dalam } \\
\text { kaitannya dengan } \\
\text { bagaimana orang } \\
\text { mengkomunikasika } \\
\text { n nilai, status, } \\
\text { kepribadian, } \\
\text { identitas, dan } \\
\text { perasaan kepada } \\
\text { orang lain. Tetapi } \\
\text { fashion selalu } \\
\text { mengadopsi }\end{array}$ & $\begin{array}{l}\text { Mode busana } \\
\text { award pada } \\
\text { umumnya } \\
\text { menjadi trend } \\
\text { setter dalam } \\
\text { dunia fashion. } \\
\text { Penampilan } \\
\text { busana award } \\
\text { agar terlihat } \\
\text { mewah bisa } \\
\text { dilakukan } \\
\text { dengan } \\
\text { menerapkan } \\
\text { garniture } \\
\text { busana. } \\
\text { Garniture } \\
\text { seperti apa } \\
\text { yang digunakan }\end{array}$ & $\begin{array}{l}\text { Kriya dianggap } \\
\text { sebuah karya seni } \\
\text { kelas dua atau } \\
\text { kelas bawah } \\
\text { bahkan pernah } \\
\text { dikatakan bukan } \\
\text { karya seni karena } \\
\text { dianggap kurang } \\
\text { ekspresif }\end{array}$ \\
\hline
\end{tabular}




\begin{tabular}{|c|c|c|c|c|c|}
\hline & & $\begin{array}{l}\text { sumber ide } \\
\text { penciptaan } \\
\text { sebuah karya } \\
\text { seni }\end{array}$ & $\begin{array}{l}\text { konsep modern } \\
\text { dalam } \\
\text { perkembangannya } \\
\text {, dimana fashion } \\
\text { selalu berubah } \\
\text { sesuai dengan }\end{array}$ & & \\
\hline Tujuan & $\begin{array}{l}\text { Membuat suatu karya } \\
\text { di bidang busana } \\
\text { khususnya kriya tekstil } \\
\text { berupa pembuatan } \\
\text { motif batik berupa } \\
\text { daun maple yang di } \\
\text { aplikasikan kedalam } \\
\text { busana casual yang } \\
\text { memberikan } \\
\text { kenyaman bagi } \\
\text { penggunaannya }\end{array}$ & $\begin{array}{l}\text { Karya seni berupa } \\
\text { busana ini tercipta } \\
\text { oleh penulis atau } \\
\text { pencipta dengan } \\
\text { melihat } \\
\text { permasalahan yang } \\
\text { terjadi di kalangan } \\
\text { masyarakat. Karya } \\
\text { seni ini diciptakan } \\
\text { sebagai pesan } \\
\text { terhadap } \\
\text { masyarakat dalam } \\
\text { bentuk busana } \\
\text { artwear }\end{array}$ & $\begin{array}{l}\text { Memberikan kiat } \\
\text { kiat dalam } \\
\text { menghadapi } \\
\text { hambatan- } \\
\text { hambatan } \\
\text { Dalam } \\
\text { mengekspresikan } \\
\text { diri } \\
\text { melaluifashion }\end{array}$ & $\begin{array}{l}\text { Peneliti membuat } \\
\text { karya busana award } \\
\text { dengan } \\
\text { pengaplikasian } \\
\text { garniture surface } \\
\text { cording sehingga } \\
\text { dapat menghadirakan } \\
\text { suasana mewah } \\
\text { dengan } \\
\text { Keistimewaan teknik } \\
\text { aplikasi yang akan } \\
\text { digunakan yaitu } \\
\text { dilihat dari keindahan } \\
\text { motifnya dan } \\
\text { keunikan teknik } \\
\text { pembuatannya }\end{array}$ & $\begin{array}{l}\text { Memberikan } \\
\text { pemahaman secara } \\
\text { umum pada } \\
\text { masyarakat bahwa } \\
\text { proses penciptaan } \\
\text { karya kriya dimana } \\
\text { teknik dan ekspresi } \\
\text { selalu beriringan, } \\
\text { dan yang } \\
\text { membedakan } \\
\text { adalah kapasitas } \\
\text { yang terkandung } \\
\text { didalamnya }\end{array}$ \\
\hline
\end{tabular}




\begin{tabular}{|c|c|c|c|c|c|}
\hline Manfaat & $\begin{array}{l}\text { Menghadirkan karya } \\
\text { yang dapat } \\
\text { memberikan inspirasi } \\
\text { bagi ranah seni dan } \\
\text { bidang busana } \\
\text { khususnya kriya tekstil } \\
\text { berupa pembuatan } \\
\text { motif daun maple } \\
\text { dengan teknik batik } \\
\text { pada busana casual } \\
\text { serta teknik teknik dan } \\
\text { pewarna yang } \\
\text { digunakan }\end{array}$ & $\begin{array}{l}\text { Menggambarkan } \\
\text { keadaan manusia } \\
\text { yang begadang } \\
\text { untuk melakukan } \\
\text { suatu pekerjaan. } \\
\text { Sering kali kita } \\
\text { mendengar bahwa } \\
\text { manusia yang } \\
\text { melakukan } \\
\text { pekerjaan atau } \\
\text { aktivitas pada } \\
\text { malam hari } \\
\text { disamakan dengan } \\
\text { kelelawar. Julukan } \\
\text { seperti ini sudah } \\
\text { umum dikalangan } \\
\text { masyarakat dahulu } \\
\text { hingga saat ini }\end{array}$ & $\begin{array}{l}\text { Mengekspresikan } \\
\text { diri dalam } \\
\text { berbusana dengan } \\
\text { mensiasati } \\
\text { perkembangan } \\
\text { fashion yang cepat }\end{array}$ & $\begin{array}{l}\text { Menghadirkan } \\
\text { sebuah karya busana } \\
\text { yang mana } \\
\text { menjadikan sebuah } \\
\text { pengembangan } \\
\text { dalam busana award. } \\
\text { Mode busana award } \\
\text { mempunyai sifat atau } \\
\text { penampilan yang } \\
\text { sangat kuat } \\
\text { pengaruhnya, } \\
\text { sehingga dapat } \\
\text { menarik minat } \\
\text { banyak orang dan } \\
\text { dapat menjadi trend } \\
\text { setter untuk gaya } \\
\text { berbusana pada } \\
\text { kesempatan pesta } \\
\text { malam }\end{array}$ & $\begin{array}{l}\text { Dengan } \\
\text { mengetahui secara } \\
\text { rinci peran dan } \\
\text { kedudukan teknik } \\
\text { dan } \\
\text { ekspresi dalam } \\
\text { proses penciptaan } \\
\text { karya kriya dari } \\
\text { awal kelahirannya } \\
\text { sampai pada } \\
\text { penciptaan kriya } \\
\text { dewasa ini. } \\
\text { Sehingga dapat } \\
\text { menciptakan karya- } \\
\text { karya yang } \\
\text { spektakuler dan } \\
\text { monumental dan } \\
\text { dapat mewujudkan } \\
\text { sebuah karya yang } \\
\text { universal dimana } \\
\text { segala asfek-asfek } \\
\text { estetika tersirat dan } \\
\text { terpancar dengan } \\
\text { porsi dan kekuatan }\end{array}$ \\
\hline
\end{tabular}

sebuah karya yang monumental yang patut diakui dan dihargai sebagai sebuah karya seni yang adiluhung 
Metode

\author{
Metode penelitian Metode pendekatan Metode penelitian \\ yang digunakan adalah yang digunakan \\ yang dilakukan adalah \\ Metode penelitian SP berupa Pendekatan penelitian deskriptif \\ Gustami, terdapat tiga Estetis, Pendekatan kualitatif \\ tahap penciptaan seni ergonomis, dan \\ kriya, yaitu eksplorasi, semiotika \\ perancangan, dan \\ perwujudan
}

Metode yang

digunakan dalam

penulisan karya

ilmiah ini adalah

metode studi

dokumentasi atau

studi pustaka sebagai

landasan teori untuk pembahasan kajian

pustaka dan metode

project based

learning yaitu metode

pembelajaran

berbasis proyek yang

dalam kegiatan

pemecahan masalah

dengan cara

merancang produk,

melaksanakan

pekerjaan produksi

dan mengevaluasi

produk hasil karya

guna mendapatkan

hasil produk busana

yang sesuai dengan

yang diharapkan
Metode yang

digunakan dalam

penelitian adalah

penelitian deskriptif

kualitatif

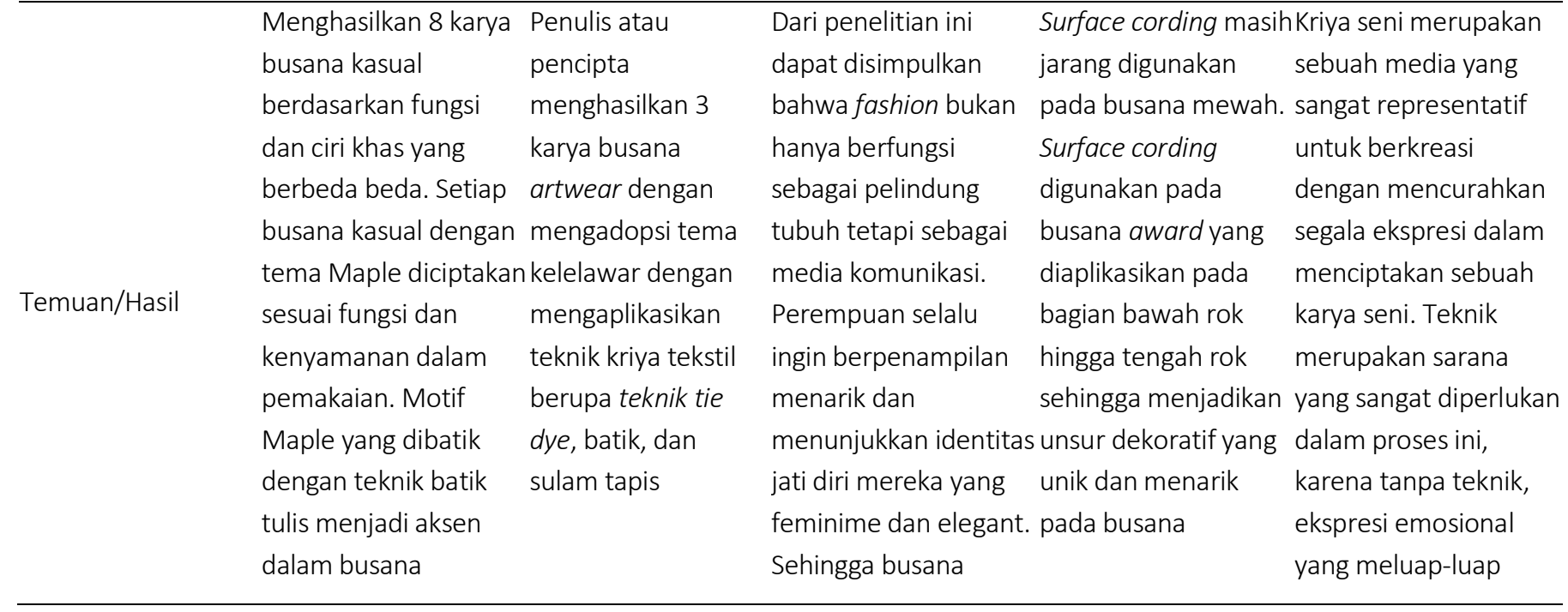




\begin{tabular}{|c|c|c|}
\hline $\begin{array}{l}\text { kasual yang } \\
\text { diciptakan }\end{array}$ & $\begin{array}{l}\text { merupakan obyek } \\
\text { untuk mendapatkan } \\
\text { nilai citra dan } \\
\text { kepercayaan diri. } \\
\text { Fashion selalu up to } \\
\text { date seiring } \\
\text { berjalannya waktu, } \\
\text { sehingga perempuan } \\
\text { mau tidak mau pasti } \\
\text { mengikuti } \\
\text { perkembangan dalam } \\
\text { bergaya. Tetapi dalam } \\
\text { mengikuti } \\
\text { perkembangan fashion } \\
\text { munculah beberapa } \\
\text { hambatan seperti segi } \\
\text { finansial, postur tubuh } \\
\text { dan karakter individu } \\
\text { yang sesuai }\end{array}$ & $\begin{array}{l}\text { tidak akan melahirkan } \\
\text { sebuah karya seni }\end{array}$ \\
\hline
\end{tabular}

Selanjutnya untuk mewujudkan busana ditentukan gaya busana dan gaya busana yang diadopsi ialah Bohemian Style, dengan informasi apa itu sebenernya gaya bohemian, asal dan ciri khas dari gaya bohemian. Pengertian dari busana artwear dan kesempatan apa yang cocok dikenakan. Dari pengertian busana artwear itu sendiri diambil kesimpulan bahwa busana ini cocok dikenakan pada saat acara award. Pada acara award, busana artwear ini sebagai bentuk ekspresi diri dalam fashion. Hasil review beberapa karya tulis ilmiah ini diharapkan busana yang akan dikerjakan nantinya menjadi seni kerajinan tangan dan fashion ini berkolaborasi menjadi kesatuan yang indah untuk dikenakan dan dilihat.

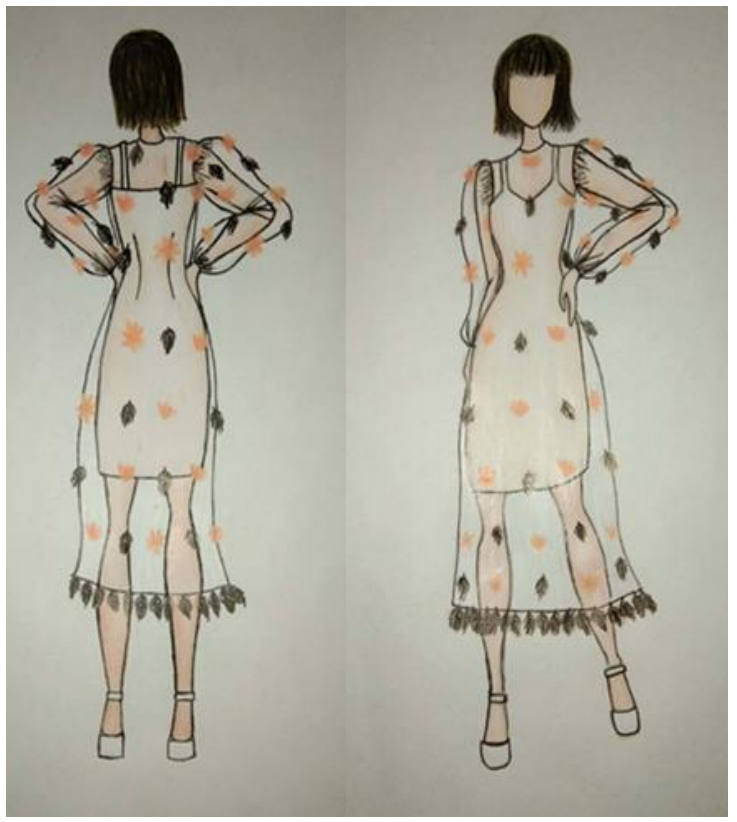

Gambar 1.1. Sketsa Produk berdasarkan review karya tulis ilmiah. Sumber : ramadhan, rofifah Muthiah, 2020

\section{PENUTUP}

Dari sepuluh artikel, jurnal, dan skripsi yang telah dibahas dapat disimpulkan dalam 
membuat busana artwear dengan bergaya bohemian dengan teknik makrame, diawali dengan mengetahui jenis dan motif daun pepohonan pada musim gugur, warna daun pada musim gugur. Mengekspresikan suasana musim gugur dengan menciptakan daun daun musim gugur yang diwujudkan dengan teknik kriya yaitu teknik makrame. Dan daun daun ini sebagai aplikasi pada busana dan menjadikannya sebuah fashion.

\section{Ucapan Terima Kasih}

Penulis ingin mengucapkan terima kasih atas bimbingan dan bantuan dari berbagai pihak yang telah membantu dalam penyusunan karya ilmiah ini. Penulis menyampaikan terima kasih kepada Dr. Suciati, S.Pd., M.Ds. sebagai dosen pembimbing penyusunan artikel ini, Dr. Marlina, M.Si. dan Feny Puspitasari, S.Pd., M.Ds. sebagai Dosen Mata Kuliah Kajian Komprehensif Bidang Busana. Diva Azzahra N.F selaku teman saya yang telah memberi semangat dan masukan terhadap diri saya.

Artikel ini merupakan bagian dari publikasi karya dari Mata Kuliah Kajian Komprehensif Bidang Busana Angkatan 2017.

\section{DAFTAR PUSTAKA}

\section{Artikel Jurnal}

Trisnawati, Yulia Tri. 2011. "Fashion sebagai Bentuk Ekspresi Diri dalam Komunikasi" dalam jurnal Universitas Semarang : Jurnal The Messenger Vol. 3 No. 1 Juli 2011.

Renata, Putri Liza. Tresna, Pipin. 2014. "Surface Cording Apllications in Award Gown" dalam jurnal Universitas Pendidikan Indonesia : Jurnal Fesyen Perspektif Vol. 4 No 92014

Suardana, Wayan i. "Komparatif Teknik dan Ekspresi dalam Seni Kriya" dalam Jurnal Universitas Negeri Yogyakarta : Jurnal Seni dan Pendidika Seni Vol 4. No. 1 2006.

\section{Buku}

Hadisunarso, Djuita, Ratna Nina. 2013 dalam Morfologi Tumbuhan, In: Morfologi Daun. Universitas Terbuka, Jakarta.

\section{Skripsi, Thesis, Disertasi, dan Laporan Penelitian}

Hakim, Febi Ramdani. (2018). Perancangan Informasi Gaya Bohemian Sebagai Alternatif Gaya Berbusana Melalui Media Lookbook. Universitas Komputer Indonesia, Bandung.

Dewi, Pradhista Olivia. (2018). Motif Daun Maple dalam Busana Kasual. Institut Seni Yogyakarta, Yogyakarta.

Sartini. (2011). Pengembangan Modul Kerajinan Makrame untuk Pembelajaran Keterampilan PKK di SMP Negeri 1 Yogyakarta. Universitas Negeri Yogyakarta, Yogyakarta.

Retnowati, Dita. (2017). Kelelawar sebagai Sumber Ide Penciptaan Busana Artwear. Institut Seni Yogyakarta, Yogyakarta.

\section{Audio/video}

Sobandi, B. (2006). Makrame (kerajinan dengan teknik simpul). Bandung : Disampaikan dalam kegiatan magang di Kampus Bumi Siliwangi

\section{Website/laman}

\section{Karya}

IImiah.

Retrieved April 13 2020, from https://id.wikipedia.org/wiki/Karya_ilmiah

10 Tips Menulis Review Artikel IImiah Yang Baik.

Retrieved May 5, 2020, from https://biologicalreviews.net/10-tips-menulisreview-artikel-ilmiah-yang-baik/

Kenapa Daun Berubah Warna Dan Berguguran Pada Musim Gugur?. Retrieved 2017, from https://sainspop.com/kenapa-daun-berubahwarna-dan-berguguran-pada-musimgugur/amp/ With Art and Fashion Collaborating Like Never Before, We Look at Some Of History's Most Important Crossovers. Retrieved September 21, 2015, from https://www.weheart.com/2015/09/21/history-art-andfashion. 